\title{
Effect of Ocean acidification on growth, calcification and recruitment of calcifying and non-calcifying epibionts of brown algae
}

\section{Effect of Ocean acidification on growth}

V. Saderne and M. Wahl

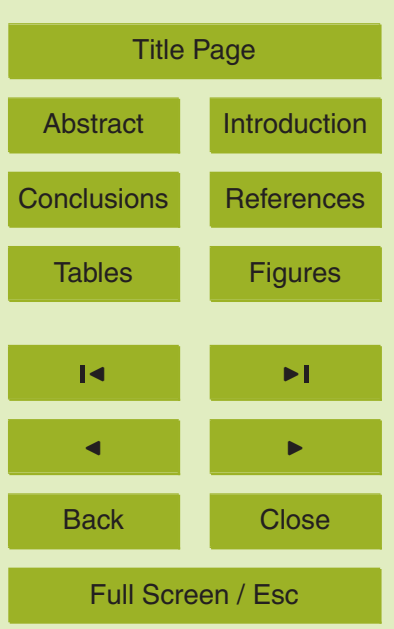

Printer-friendly Version

Interactive Discussion 


\section{Abstract}

Anthropogenic emissions of $\mathrm{CO}_{2}$ are leading to an acidification of the oceans by $0.4 \mathrm{pH}$ units in the course of this century according to the more severe model scenarios. The excess of $\mathrm{CO}_{2}$ could notably affect the benthic communities of calcifiers and macro5 phytes in different aspects (photosynthesis, respiration and calcification). Seaweeds are key species of nearshore benthic ecosystems of the Baltic Sea. They frequently are the substratum of fouling epibionts like bryozoans and tubeworms. Most of those species secrete calcified structures and could therefore be impacted by the seawater $\mathrm{pCO}_{2}$. On the other hand, the biological activity of the host may substantially modu10 late the $\mathrm{pH}$ and $p \mathrm{CO}_{2}$ conditions in the thallus boundary layer where the epibionts live. The aim of the present study was to test the sensitivity of seaweed macrofouling communities to higher $p \mathrm{CO}_{2}$ concentrations. Fragments of the macroalga Fucus serratus bearing the calcifiers Spirorbis spirorbis (Annelida) and Electra pilosa (Bryozoa) and the non-calcifier Alcyonidium gelatinosum (Bryozoa) were maintained for 30 days under three $p \mathrm{CO}_{2}$ conditions: natural $460 \pm 59 \mu \mathrm{atm}$ and enriched $1193 \pm 166 \mu \mathrm{atm}$ and $3150 \pm 446 \mu a t m$. Our study showed a significant reduction of growth rates and recruitment of Spirorbis individuals only at the highest $p \mathrm{CO}_{2}$. At a finer temporal resolution, the tubeworm recruits exhibited enhanced calcification of $40 \%$ during irradiation hours compared to dark hours, presumably due to the effect of photosynthetic and respiratory activities of the host alga on the carbonate system. Electra colonies showed significantly increased growth rates at $1193 \mu \mathrm{atm}$. No effect on Alcyonidium colonies growth rates was observed. Those results suggest a remarkable resistance of the algal macro-epibiontic communities to the most elevated $p \mathrm{CO}_{2}$ foreseen in year 2100 for open ocean ( $1000 \mu \mathrm{atm})$ conditions possibly due to the modulation of environmental conditions by the biological activities of the host alga.
BGD

9, 3739-3766, 2012

\section{Effect of Ocean acidification on growth}

V. Saderne and M. Wahl

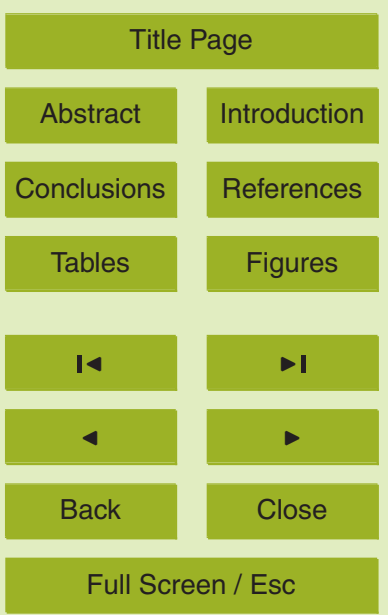

Printer-friendly Version

Interactive Discussion 


\section{Introduction}

Carbon dioxide is essential to the functioning of the global ecosystem. It is the substrate of photosynthesis for production of organic matter and gaseous oxygen. Atmospheric gas composition is a major driver of the evolution of species. Examples are the appear5 ance and spreading of $\mathrm{C} 4$ plants since the cretaceous with the low $p \mathrm{CO}_{2}$ (Collatz et al., 1998; Prentice and Harrison, 2009) or the giant arthropods in the high $p \mathrm{O}_{2}$ and $p \mathrm{CO}_{2}$ late Paleozoic (Graham et al., 1995). That era ( -415 to $-250 \mathrm{My})$ has seen the reduction of atmospheric $p \mathrm{CO}_{2}$ from 5000 to less than $1000 \mu$ atm by intense burial into fossil fuels (COPSE model, Bergman et al., 2004). Those stocks became the energy source of human societies in the 20th century, abruptly releasing the buried $\mathrm{CO}_{2}$ in the atmosphere. The ocean is in gaseous equilibrium with the atmosphere. $\mathrm{CO}_{2}$ is an acidic gas and its dissolution leads to the release of $\mathrm{H}^{+}$ions and reduction of seawater $\mathrm{pH}$. This phenomenon of ocean acidification is already responsible for a drop of $0.1 \mathrm{pH}$ units since the preindustrial time, corresponding to a $p \mathrm{CO}_{2}$ shift from 280 to $380 \mu$ atm (Orr et al., 2005). The most severe scenarios are predicting a peak of atmospheric $p \mathrm{CO}_{2}$ of $1400 \mu \mathrm{atm}$ during the 23th century (Ridgwell et al., 2007). This transition will increase the corrosiveness of seawater to the calcium carbonate forming the shells and skeletons of numerous marine species. First impacted will be the calcareous formations under the crystalline form of calcite containing a high percentage of $\mathrm{MgCO}_{3}$ (ex: echinoderms, coralline algae), followed by the ones under the form of aragonite (ex: scleratinian corals), and finally the ones with low $\mathrm{MgCO}_{3}$ (ex: oysters) (Morse et al., 2006; Fabry et al., 2008; Ries, 2011). The corrosiveness of seawater to aragonite and calcite are expressed by the saturation states: $\Omega a_{\text {rag }}$ and $\Omega_{\text {calc }}$. When $\Omega_{x} \leq 1 \mathrm{CaCO}_{3}$ tends to dissolve whereas when $>1$ it tends to precipitate. Surface waters of the Baltic 25 Sea are naturally more corrosive to $\mathrm{CaCO}_{3}$ than open ocean waters because of the low alkalinity/salinity of the water added to the low temperature in winter and the occasional upwelling of deep hypoxic waters in summer (Thomas and Schneider, 1999). During upwelling events, $p \mathrm{CO}_{2}$ up to $2500 \mu$ atm was recorded (Thomsen et al., 2010;
BGD

9, 3739-3766, 2012

Effect of Ocean acidification on growth

V. Saderne and M. Wahl

Title Page

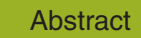

Introduction

Conclusions

Tables

References

Figures

14

$\rightarrow 1$

4

Back

Close

Printer-friendly Version

Interactive Discussion 
Saderne, 2012). Tyrrell et al. (2008) suggested the high $p \mathrm{CO}_{2} / \mathrm{low} \mathrm{CO}_{3}^{2-}$ in winter as a cause of the absence of coccolithophores in the Baltic. Fucoids are key species of the Baltic nearshore benthic habitats providing primary producer services, spawning and nursery areas, food source as well as substratum for macrofoulers (Boaden et al., 5 1975; Kautsky et al., 1992). Macrobial epibionts associated with Western Baltic macrophytes are mostly composed of filamentous algae, barnacles (mostly Amphibalanus improvisus), the tubeworm Spirorbis spirorbis and several species of Cheilostomes bryozoans (Hagerman et al., 1966). These macrofoulers are very important for/play an important role in seaweed ecology. Spirorbis spirorbis can overgrow fucoidblades (O'Connor and Lamont, 1978; Kersen et al., 2011) presumably causing shading and increases in weight and brittleness. The photosynthetic activity of Fucus serratus is reduced by 50 and $85 \%$ due to the covering by Electra pilosa and Alcyonidium hirsutum, respectively (Oswald et al., 1984). Bryozoans contribute to the degeneration of the underlying thallus and enhance the risk of breakage by wave action (Dixon, 1981; Krumhansl and Scheibling, 2011). In kelp forests (Laminaria sp.) this can lead to extensive defoliation and severely impact algae reproduction (spore release) (Saier and Chapman, 2004), affecting the entire ecosystems and ultimately stocks of commercially important species such as lobsters (Wharton and Mann, 1981; Scheibling et al., 1999). On the other hand, bryozoans are increasing habitat diversity and improving biodiver20 sity (Cocito, 2004). They directly supply the host algae with ammonium (Hurd et al., 1994) and dissolved inorganic carbon (DIC) (Munoz et al., 1991) and are a food source for grazers such as nudibranchs and urchins (Seed, 1976; Harvell, 1984; Nestler and Harris, 1994).

Within this study we tested the hypothesis that ocean acidification disadvantages calSpirorbis spirorbis and two bryozoan species, the calcifying cheilostome Electra pilosa and the keratinous Gymnolaete Alcyonidium hirsutum were investigated regarding their growth, calcification and recruitment (spirorbis only) during 30 days of incubation under three $\mathrm{pCO}_{2}$ conditions. In addition, we tested the hypothesis that the diurnally

BGD

9, 3739-3766, 2012

Effect of Ocean acidification on growth

V. Saderne and M. Wahl

Title Page

Abstract

Introduction

Conclusions

Tables

References

Figures

14

$\rightarrow 1$

4

Back

Close

Full Screen / Esc

Printer-friendly Version

Interactive Discussion 
fluctuating physiological activity of the host alga will create conditions in the boundary layer which are favorable or disfavorable for calcification of the epibionts during times of net uptake (day) and net release (night) of $\mathrm{CO}_{2}$ respectively. In this respect, growth rates of spirorbis recruits were assessed under light and dark conditions and the three $5 \mathrm{pCO}_{2}$ levels.

\section{Materials and methods}

\subsection{Animal collection}

Fucus serratus individuals fouled by Spirorbis spirorbis, Electra pilosa and Alcyonidium hirsutum were collected in less than $2 m$ depth in Eckernförde Bay (Western Baltic Sea, 10 Germany, $\left.54^{\circ} 27^{\prime} \mathrm{N}, 9^{\circ} 53^{\prime} \mathrm{E}\right)$ on 1 February 2011.

The bryozoans Electra pilosa and Alcyonidium hirsutum are colonial filter feeders. The colonies are composed of box like subunits called zooids. They are protected by a skeleton of calcium carbonate (Electra) or keratin (Alcyonidium) pierced of channels connecting the zooids to their neighbors. These connections allow the allocation of energy to the budding edge of the colony making it a single organism with deciduous organs (Lidgard and Jackson, 1989). Spirorbis spirorbis is a filter feeding tubeworm of maximum $5 \mathrm{~mm}$ length protected by a spiraled calcified tube. The tube is secreted by glands located under a collar between the head and the thorax (Nott and Parkes, 1975). Embryos are brooded within the calcareous tube in an egg bag attached to the parental body (Knight-Jones et al., 1972). Swimming non-feeding larvae are emitted in correlation with environmental factors. Settlement and metamorphosis into a juvenile tubeworm occur within few hours (Knight-Jones, 1951).

\subsection{Acclimation and staining}

Algae and animals were acclimated under ambient $p \mathrm{CO}_{2}$ (400 to $500 \mu$ atm) during seven days prior to the experiment. Cultivation was made in constant temperature

\section{BGD}

9, 3739-3766, 2012

\section{Effect of Ocean acidification on growth}

V. Saderne and M. Wahl

Title Page

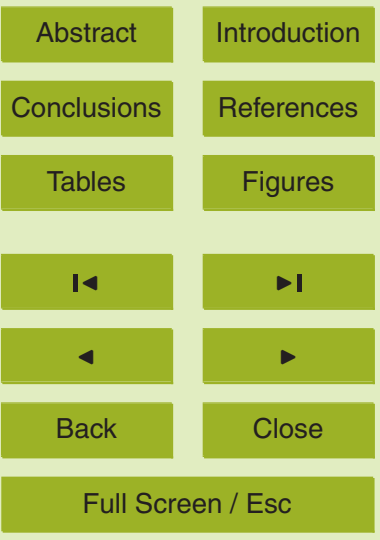

Printer-friendly Version

Interactive Discussion 
room at $15^{\circ} \mathrm{C}$. Light was provided by three Biolux neon tubes (Osram, Germany), delivering $300 \mu \mathrm{E}$ under $12 \mathrm{~h}$ day/night cycles. Animals were fed ad libitum with microalgae Rhodomonas sp. This microalga species is a convenient food source for bryozoans and spirorbis (Hermansen et al., 2001; Lisbjerg and Petersen, 2001). After two days, equiv5 alently fouled sections of one fucus thallus of $1 \pm 0.13 \mathrm{~g}$ were cut. Mean \pm SD numbers of macrofoulers per section were $26.8 \pm 16.8$ Spirorbis, $6.2 \pm 6.1$ colonies of Electra pilosa and $1.9 \pm 1.8$ colonies of Alcyonidium hirsutum. Animals were stained for five days with calcein/seawater at $50 \mathrm{mg} \mathrm{I}^{-1}$. Calcein is a vital fluorescent dye which chelates $\mathrm{Ca}^{2+}$ and $\mathrm{Mg}^{2+}$ ions, incorporating into growing shells and skeletons and thereby set10 ting a mark for later measurements of their growth rates (see Fig. 1) (Smith et al., 2001; Comeau et al., 2009; Dissard et al., 2009).

\subsection{Maintenance system}

30 fucus sections of the initial pool were incubated in $650 \mathrm{ml}$ tissue culture flasks (Sarstedt, Germany) randomly distributed between the three $p \mathrm{CO}_{2}$ treatments. Treated flasks were aerated at $460 \mu$ atm $\mathrm{CO}_{2}$ (ambient), $1200 \mu$ atm $\mathrm{CO}_{2}$ and $3000 \mu$ atm $\mathrm{CO}_{2}$ using an automatic system mixing $\mathrm{CO}_{2}$ with ambient air (Linde gas and HTK Hamburg, Germany) (see Thomsen et al., 2010 for details). The gas bubbling assured a continuous mixing of the test water. Natural Baltic seawater from the Kiel Bight (Western Baltic Sea, Germany, 54 $19^{\prime} \mathrm{N}, 10^{\circ} 08^{\prime} \mathrm{E}$ ) was used in the experiment, after storage in a 300I tank and sterilized by a Microfloat 1 floating UV lamp (Aqua Concept Karlsruhe, Germany) and aerated with ambient air. The stock was regularly renewed. Before use, the seawater was equilibrated with the three $p \mathrm{CO}_{2}$ treatment levels in three separate tanks for $24 \mathrm{~h}$. The seawater of the flasks was renewed every third day and the animals fed thereafter with Rhodomonas sp. to a final concentra25 tion of 10000 cells ml${ }^{-1}$. The concentrations of the stock cultures were assessed with a Coulter Counter (Beckman Coulter, USA). After 30 days of incubation, algal fragments were fixed and conserved in borax-formaldehyde-seawater solutions suitable for
BGD

9, 3739-3766, 2012

Effect of Ocean acidification on growth

V. Saderne and M. Wahl

Title Page

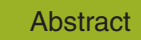

Introduction

Conclusions

Tables

References

Figures

14

$\rightarrow 1$

4

Back

Close

Printer-friendly Version

Interactive Discussion 
preservation of calcareous structures (see Maybury and Gwynn, 1993, for the detailed recipe) prior to fluorescence microscopy analyses of stained bands and growth rates.

\subsection{Seawater chemistry}

Seawater processing for carbonate system measurements was made according to the 5 standard operating procedure (SOP) 1 of Dickson and Sabine (2007). Three random flasks in each treatment and the three mixing tanks were sampled for seawater prior to each water exchange. The temperature of the flasks and the tanks were measured with $0.01^{\circ} \mathrm{C}$ precision for future in-situ $\mathrm{pH}$ recalculation (see below). Samples were analyzed in the laboratory for DIC and $\mathrm{pH}_{\text {tot }}$. DIC was measured with an AIRICA (Marianda, 10 Germany), the measurement principle is based on the Infrared measurement of $\mathrm{CO}_{2}$ (g) purged out of an acidified sample. The system was calibrated on every measurement day with Certified Reference Material (CRM) (Andrew Dickson, Scripps Institution of Oceanography). The $\mathrm{pH}$ on total scale was measured as follows. Seawater TRIS pH buffers for 15 psu were made according to the SOP 6a of Dickson and Sabine (2007).

15 A combined reference/measurement electrode Metrohm Ecotrode (Metrohm, Switzerland) was used together with a pH-meter/conductimeter Mettler-Toledo SG 7/8 (Mettler Toledo, Switzerland). For calibration, the TRIS buffer was immersed in a thermostatic bath and the voltage $( \pm 0.1 \mathrm{mV})$ of the $\mathrm{pH}$ electrode was measured. The temperature of the buffer was modulated on a range of $1.5^{\circ} \mathrm{C}$. The temperature corresponding to every $\mathrm{mV}$ change was recorded with $>0.01^{\circ} \mathrm{C}$ accuracy with a Fluke 5658 reference thermometer equipped with a 5608 platinum resistance sensor (Fluke, USA). The procedure was repeated by increasing and decreasing the temperature to get an average voltage $(\mathrm{mV})$ versus $T\left({ }^{\circ} \mathrm{C}\right)$ reference curve for the electrode in the buffer. The fitting of the electrode voltage to the curve was assessed on every measurement day to check

\section{BGD}

9, 3739-3766, 2012

Effect of Ocean acidification on growth

V. Saderne and M. Wahl

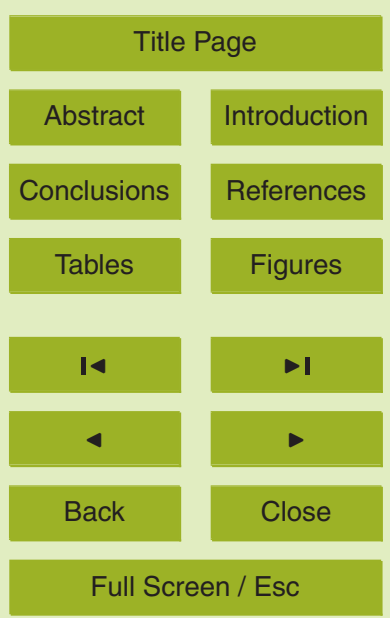

Printer-friendly Version

Interactive Discussion temperature corresponding to the calibration range. The sample voltage, sample temperature and the theoretical TRIS buffer voltage (corresponding through the calibration 
curve to the sample temperature) were computed through the equation of the SOP $6 a$ to obtain the laboratory $\mathrm{pH}$ on total scale of the sample. The temperature of the sample measured the climate room at the time of sampling was used to recalculate the in-situ $\mathrm{pH}$. Preparative work conducted on CRM together with $35 \mathrm{psu}$ buffers demonstrated an 5 accuracy of this method of 0.003 to $0.005 \mathrm{pH}$ units. Salinity of the samples was measured to an accuracy of $0.01 \mathrm{psu}$ with a Mettler Toledo Inlab 738 conductivity probe after calibration at $25^{\circ} \mathrm{C}$ with $\mathrm{KCl} 0.1 \mathrm{moll}^{-1}$ (Fischer Scientific, USA). The overall in situ-pH and carbonate system was recalculated with the $\mathrm{R}$ package Seacarb (Lavigne and Gattuso, 2011) using first and second carbonate system dissociation constants 10 for estuarine systems from Millero (2010) and the dissociations constants of HF and $\mathrm{HSO}_{4}^{-}$of Perez and Fraga (1987) and Dickson (1990).

\subsection{Measurement of relative growth rates (RGR) of the bryozoans}

Colonies were photographed by overlapping fields of vision under epifluorescence microscope (Axio Scope A1, Carl Zeiss, Germany) at the end of the experiment. The partial pictures were reassembled into complete colony pictures. The initial colony surface (SI) (pre-staining) and the final surface (SF) (after 30 days incubation) were measured by image analysis (ImageJ, US National Institutes of Health). The relative growth rate in percent (RGR) was calculated as follows:

$\mathrm{RGR}=\left[\ln \left(\sum_{j=1}^{n} \mathrm{SF} j\right)-\ln \left(\sum_{j=1}^{n} \mathrm{SI} j\right)\right] \cdot 100$

With $n$ the number of colonies in one flask. The logarithmic growth pattern of bryozoans colonies have been assessed by Hermansen et al. (2001). Alcyonidium hirsutum colonies (non-stainables), were photographed prior and after incubation. The areas were measured and the RGR calculated as for Electra pilosa.
BGD

9, 3739-3766, 2012

Effect of Ocean acidification on growth

V. Saderne and M. Wahl

Title Page

Abstract

Introduction

Conclusions

Tables

References

Figures

14

$\rightarrow$

4

Back

Close

Full Screen / Esc

Printer-friendly Version

Interactive Discussion 


\subsection{Measurement of growth and recruitment of Spirorbis spirorbis}

Spirorbis tube growth in mm was estimated as the length of the external arc of the coil comprised between the staining front and the tube edge (see Fig. 1a and b). In each flask, the new tube length of all worms was summed and divided by the number of

5 worms. Spirorbis recruitment was quantified for each flask as the number of juveniles found on algae sections at the end of the experiment divided by the number of adults.

\subsection{Effect of light on the growth of Spirorbis spirorbis juveniles}

To test the effect of photosynthetic activity and $p \mathrm{CO}_{2}$ on the growth of juvenile worms in the thallus boundary layer, calcein was added to all the flasks (final concentration: $1020 \mathrm{mg} \mathrm{l}^{-1}$ ) during the last $24 \mathrm{~h}$ of the experiment, half of the flasks were kept in constant light, the other half was darkened with aluminum foils. Growth was measured as the size of the stained newly formed tube (see Fig. 1c and d).

\subsection{Statistical analysis}

Statistical analyses were conducted with Statistica 7 (Statsoft, USA). Treatments were compared using one way ANOVAs and Tukey's HSD tests. Assumption of normality and homoscedasticity were tested with Shapiro-Wilk's and Levene's tests. In case of abnormality a transformation by natural logarithm was done.

\section{Results}

\subsection{Chemistry}

20 A summary of the variables of the carbonate system measured in the flasks during the 30 days duration of the experiment derived from $\mathrm{pH}_{\text {tot }}$ and $\mathrm{DIC}$ are presented in Table 1. Average $( \pm \mathrm{SD}) p \mathrm{CO}_{2}$ were $460 \pm 59 \mu \mathrm{atm}, 1193 \pm 166 \mu \mathrm{atm}$ and

\section{BGD}

9, 3739-3766, 2012

\section{Effect of Ocean acidification on growth}

V. Saderne and M. Wahl

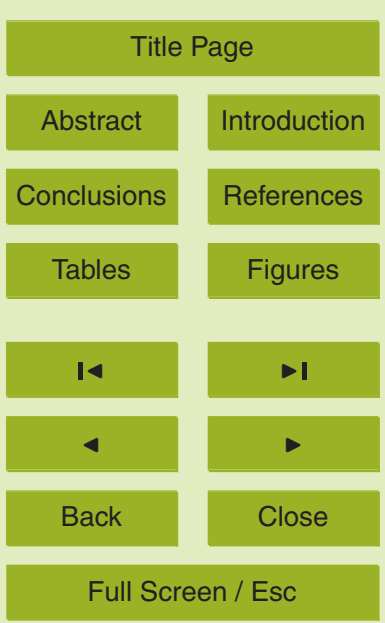

Printer-friendly Version

Interactive Discussion 
$3150 \pm 445 \mu \mathrm{atm}$ respectively for the control and the two elevated treatments. Saturation states (mean $\pm S D$ ) below one, for aragonite $(0.82 \pm 0.14)$ and for calcite $(0.66 \pm 0.14)$ were reached in the $1200 \mu \mathrm{atm}$ and in the $3150 \mu \mathrm{atm} p \mathrm{CO}_{2}$ treatments, respectively.

\subsection{Spirorbis spirorbis}

The average $\pm S D$ of newly formed tube within 30 days were $0.95 \pm 0.32,0.83 \pm 0.05$ and $0.58 \pm 0.15 \mathrm{~mm}^{-1}$ worm $^{-1} \mathrm{flsk}^{-1}$ in the control, $1120 \mu \mathrm{atm}$ and $3150 \mu \mathrm{atm}$ treatments (Fig. 2a) respectively. The growth of spirorbis tubes was significantly affected by $p \mathrm{CO}_{2}$ (one way ANOVA, $p \leq 0.01$ ). Reductions of growth rates were found at $3150 \mu$ atm com10 pared to the $460 \mu$ atm (Tukey's HSD, $p \leq 0.01$ ) and, marginally, relative to $1200 \mu a t m$ (Tukey's HSD, $p \leq 0.1$ ). While no signs of shell injuries were visible at $460 \mu$ atm and $1200 \mu \mathrm{atm}$, all spirorbis tubes exhibited substantial shell dissolution at $3150 \mu \mathrm{atm}$ (see Fig. 1a and b). This loss of integrity affected principally the outer spiral of the tube exposing the worm soft bodies and the embryo bags to the external seawater. Recruitment of spirorbis was significantly affected by $p \mathrm{CO}_{2}$ (one way ANOVA, $p \leq 0.001$ ) (Fig. 2b). The numbers of settled juveniles per adults were significantly

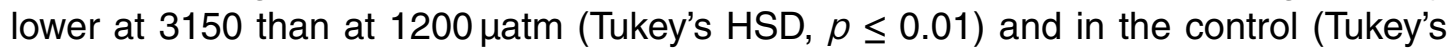
$\mathrm{HSD}, p \leq 0.001$ ) with mean $\pm \mathrm{SD}$ densities respectively of $1.76 \pm 1.5,7.63 \pm 6.7$ and $9.34 \pm 4.7$ juv worm ${ }^{-1}$. Juvenile tubes growth rates were significantly enhanced under corresponding to a $39.5 \%$ difference (Factorial ANOVA, $p \leq 0.001$; Fig. 3 ). The $p \mathrm{CO}_{2}$ treatments produced no significant effect on the juvenile's growth rates but important damages on the early tubes were observed in the $3150 \mu$ atm treatment (see Fig. 1c and d).

BGD

9, 3739-3766, 2012

Effect of Ocean acidification on growth

V. Saderne and M. Wahl

Title Page

Abstract

Introduction

Conclusions

References

Tables

Figures

14

$\rightarrow$

4

Back

Close

Full Screen / Esc

Printer-friendly Version

Interactive Discussion 


\subsection{Bryozoans}

$p \mathrm{CO}_{2}$ had a significant effect on growth rates of Electra pilosa (one way ANOVA, $p \leq 0.05)$ enhancing colony growth at the intermediate acidification level, $1200 \mu$ atm $(76.5 \pm 31.7 \%)$, relative to the highest level, $3150 \mu$ atm $(43.0 \pm 32.2 \%)$ (Tukey's HSD, $5 p \leq 0.01$ ) (Fig. $4 \mathrm{a}$ ) which was similar to the low $p \mathrm{CO}_{2}$ treatment $(50.7 \pm 18.1 \%)$. In this highest $p \mathrm{CO}_{2}$ treatment, the skeleton of uninhabited zooids dissolved completely, resulting in a "ghost" organic matrix of the exact same shape.

Relative growth rates of Alcyonidium were similar under all $p \mathrm{CO}_{2}$ levels: $27.2 \pm 25.5 \%$ in the control, $36.5 \pm 40.8 \%$ in the $1200 \mu a t m$ treatment and $1019.18 \pm 17.9 \%$ in the $3500 \mu$ atm treatment (ANOVA, $p>0.1$; Fig. $4 b$ ).

\section{Discussion}

The present study demonstrated that the calcifying tubeworm Spirorbis spirorbis was affected in its growth and recruitment at $3150 \mu$ atm $\mathrm{CO}_{2}$. In this treatment, adults and juveniles shells were exhibiting important damages due to dissolution. The growth rates of the juveniles were not affected directly by $p \mathrm{CO}_{2}$ but by irradiation, attesting to a protective effect of photosynthesis of Fucus on the calcifying organisms living in the boundary layer surrounding the thallus. In the boundary layer $(<1 \mathrm{~mm}$ off the thallus surface) conditions $\left(\mathrm{O}_{2}, \mathrm{pH}\right)$ have been shown to fluctuate by orders of magnitude between light and dark phases (De Beer and Larkum, 2001; Beer et al., 2008; Spilling et al., 2010), affecting the physiology of the incrusted animals (Woods and Podolsky, 2007). The bryozoans Electra pilosa and Alcyonidium hirsutum were marginally affected in their growth by the $\mathrm{pCO}_{2}$ regardless of the nature of their skeletons. However, the dissolution of the empty skeletons at $3150 \mu \mathrm{atm} \mathrm{CO}_{2}$ was noted for Electra pilosa.

BGD

9, 3739-3766, 2012

Effect of Ocean acidification on growth

V. Saderne and M. Wahl

Title Page

Abstract

Introduction

Conclusions

References

Tables

Figures

14

4

Back

Close

\section{Full Screen / Esc}

Printer-friendly Version

Interactive Discussion 


\subsection{Bryozoans}

Our results suggest that the growth in the bryozoan Electra pilosa is not negatively affected by very high $p \mathrm{CO}_{2}$ and even stimulated at $1200 \mu$ atm. However, the empty zooids lost their calcified structures at $3150 \mu$ atm, when the seawater was undersatu-

5 rated with regard to calcite. These results could be explained by the known mineralogy of Electra pilosa. Their skeleton is exclusively calcitic with 7 to $10 \%$ of $\mathrm{MgCO}_{3}$ (Rucker and Carver, 1969; Smith et al., 2006; Taylor et al., 2009), reminiscent of the appearance of this sub-order in the calcitic seas of the late Jurassic/Cretaceous (Stanley, 2006). In the natural $\mathrm{CO}_{2}$ vents of Ischia (Italy), Rodolfo-Metalpa et al., (2010) found mainte10 nance of growth and calcification of transplanted colonies of the bryozoan Myriapora truncata at $1400 \mu \mathrm{atm} p \mathrm{CO}_{2}$, and $\Omega_{\text {calc }}=3.08$ but dissolution of dead zooid skeletons. Dead Baltic Electra pilosa skeletons dissolved only when $\Omega_{\text {calc }} \leq 1$ (3150 $\mu$ atm treatment) and therefore seem more resistant to seawater corrosiveness. Nevertheless, both our results corroborate the important role of the zooidal tissues surrounding 15 the skeletons of bryozoans, presumably creating a barrier to corrosive seawater. Such protective effects of external living tissues and organic layers over calcified structures have already been observed in mussels and corals (Rodolfo-Metalpa et al., 2011). Calcification processes in bryozoans are largely unstudied but the functioning of the calcein staining could give a first clue into the process. Bentov et al. (2009) suggest that calcein staining of biomineralized structures implies direct vacuolization of seawater. The classes of calcifiers using this mechanism are presumably the most sensitive to the environmental $\mathrm{pH}$ (Weiner and Dove, 2003; Weiner and Addadi, 2011) as they use external seawater at the sites of calcification. Within the order of the Cheilostomata, calcein staining worked with the genera Electra (sub-order: Malacosteginae, this study) and Adeonellopsis, (sub-order: Ascophorae, Smith et al., 2001) but not with Flustra (sub-order: Flustridae, Fortunato and Saderne, unpublished), suggesting different mechanisms of calcification within the cheilostomes. Cheilostome bryozoans evolved calcareous skeletons polyphyletically on at least two distinct occasions and

\section{BGD}

9, 3739-3766, 2012

Effect of Ocean acidification on growth

V. Saderne and M. Wahl

Title Page

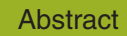

Introduction

Conclusions

Tables

References

Figures

14

$\rightarrow$

4

Back

Close

Printer-friendly Version

Interactive Discussion 
as a consequence possess diverse calcified structures that could be based on different calcification mechanisms (Jablonski et al., 1997; Smith et al., 2006; Taylor et al., 2009).

The growth response of Alcyonidium hirsutum to $p \mathrm{CO}_{2}$ followed the same pat5 tern as for Electra pilosa but with growth rates $50 \%$ slower. These results are similar to observations in the field. Electra pilosa tends to dominate Fucus blades by its rapid growth rates (Ryland and Stebbing, 1971) while Alcyonidium, less competitive for space, seems more ubiquist in term of habitats colonized (O'Connor and Lamont, 1978).

\subsection{Calcification of Spirorbis spirorbis}

Reduction of growth and shell damages were observed only when seawater reached undersaturation for calcite at the highest level of acidification (3150 $\mu \mathrm{atm})$. Our findings differ from previous results obtained on the serpulid polychaete Hydroides crucigera by Ries et al. (2009). They found a linear decrease of calcification with increasing $p \mathrm{CO}_{2}$ 15 from 280 to $2800 \mu$ atm. This difference might be due to the difference in mineralogy between the two species. Hydroides crucigera tubes are bimineralic with $40 \%$ aragonite and $60 \%$ calcite including $20 \% \mathrm{Mg}$ calcite (Ries, 2011), while spirorbis tubes are almost exclusively calcitic with $15 \% \mathrm{MgCO}_{3}$ (Bornhold and Milliman, 1973). Generally, serpulids exhibit a wide variety of tube ultrastructure and mineralogy, most of them being bimineralic (Vinn et al., 2008). Their mineralogy seems to be modulated by the saturation state of seawater. In exclusively calcitic serpulids, predominance of low $\mathrm{Mg}$ calcite in tubes is observed at high latitude in cold corrosive seawater compared to tropical species (Bornhold and Milliman, 1973). In bimineralic species, no geographic relationship between seawater corrosiveness and low aragonite content in tubes is ob-
BGD

9, 3739-3766, 2012

\section{Effect of Ocean acidification on growth}

V. Saderne and M. Wahl

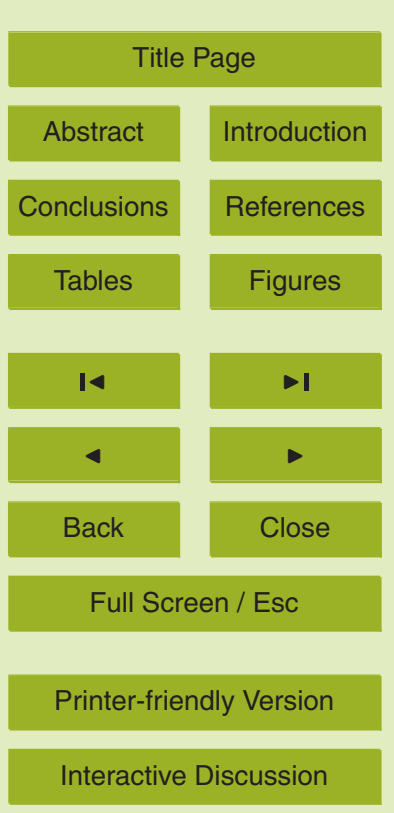


even if the absence of organic covering protecting their tubes might limit their capacities of adaptation of calcification to corrosive waters.

\section{3 recruitment and juvenile growth of Spirorbis spirorbis}

Breading of Spirorbis larvae in the parental tube varies between 10 to 25 days, depend5 ing on seawater temperature (Daly, 1978) and settlement occurs within a few hours (Knight-Jones, 1951). In our experiment the first juveniles appeared after two weeks. Their number was reduced by $80 \%$ in the $3150 \mu$ atm treatment relative to the low acidification condition. This was associated with the observation of numerous unspawned eggs bags in the adult tubes. Kurihara (2008) identified five critical early life stages in 10 invertebrates: fertilization, cleavage (embryogenesis), planktonic larva, settlement and metamorphosis. Accidents having happened to those early life stages could explain our results. Exchange of sperm and fertilization of eggs might not have occurred during the experiment since sperm stored during the previous summer in a specific organ of the head could have been used to fertilize the eggs (Potswald, 1967; Daly and Golding, 1977). Likewise, some embryos in dormancy at the beginning of the experiment could have seen their development reactivated. A delaying or interruption of the embryogenesis is a possible explanation for our results, due to the exposition of the embryo bags to external acidified seawater after dissolution of the parental tubes. Such embryogenesis accidents have been noted for gastropods, bivalves and echinoderms (Desrosiers et al., 1996; Kurihara and Shiryama, 2004; Ellis et al., 2009). The planktonic stage is another sensitive life stage for invertebrates on which ocean acidification can be deleterious (Dupont et al., 2008; Kurihara, 2008). In Spirorbis, however, the shortness of the pelagic phase (a few minutes to $3 \mathrm{~h}$ ) and the non-calcifying nature of the larvae may reduce the impact of acidified seawater. Spirorbis spirorbis specifically settles on brown 1985; Qian, 1999). The necessary sensitivity to cues could be affected by seawater $\mathrm{pH}$ and making the larvae incapable of recognizing their hosts. This has been found in clown fish (Amphiprion percula) larvae, becoming "blind" to their host anemones cues

BGD

9, 3739-3766, 2012

Effect of Ocean acidification on growth

V. Saderne and M. Wahl

Title Page

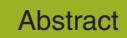

Introduction

Conclusions

Tables

References

Figures

14

$\rightarrow$

4

Back

Close

Full Screen / Esc

Printer-friendly Version

Interactive Discussion 
under high $p \mathrm{CO}_{2}$ (Munday et al., 2009). Reduction of settlement could also be caused by an increase of the algae defenses at elevated $p \mathrm{CO}_{2}$. Algal metabolites have an inhibiting and/or facilitating effect on foulers. Those effects can be direct (e.g. Wahl et al., 2010), or indirect by the mean of the microbial biofilms (Lau and Qian, 1997; Harder 5 et al., 2002; Nasrolahi et al., 2012). So far no ocean acidification studies on seaweeds defenses have been made.

As a novel aspect of epibiotic associations, our study strongly suggests that juvenile spirorbis benefit from algal photosynthesis which creates temporarily conditions favorable for calcification even under severe ocean acidification. The growth rate of the 10 juveniles was about $40 \%$ faster under light than in the dark. Settlement, metamorphosis and early growth of Spirorbis spirorbis takes place in the boundary layer adhering to the thallus surface of Fucus. In this layer of $300 \mu \mathrm{m}$ to $1 \mathrm{~mm}$ thick, $\mathrm{pH}$ can be pushed to beyond 9 in daytime by the $\mathrm{CO}_{2}$ uptake associated with photosynthesis (Fischer and Saderne, unpublished data). Under dark conditions, in contrast, the decrease of $\mathrm{pH}$ due to algal respiration seems marginal (De Beer and Larkum, 2001; Beer et al., 2008; Spilling et al., 2010). We may expect that similar phenomena take place in natural stands of marine macrophytes (algae, seagrasses) where the population's combined photosynthesis pushes the habitat's saturation state to favorable conditions and allows calcifiers in the community to produce skeleton material during certain daylight hours.

One widespread expectation about ocean acidification is that non-calcified organisms will outcompete calcifying organisms (Fabry et al., 2008) as observed between corals and seaweeds (Diaz-Pulido et al., 2011). A shift to non-calcifying epibionts is observed under high $p \mathrm{CO}_{2}$ observed in Mediterranean seagrasses due to the disappearance of coralline algae (Kuffner et al., 2007; Martin et al., 2008). Our study does not suggest such an effect. In our experiment, epibionts of Fucus serratus resisted future $p \mathrm{CO}_{2}$ conditions predicted for the open ocean. Part of this resistance may have been caused
BGD

9, 3739-3766, 2012

\section{Effect of Ocean acidification on growth}

V. Saderne and M. Wahl

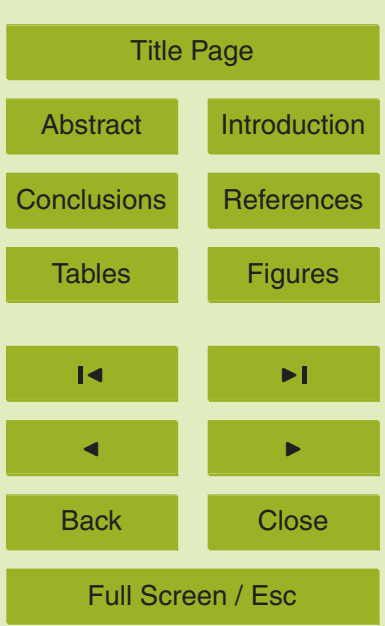

Printer-friendly Version

Interactive Discussion 
by the alga's photosynthetic activity overriding the simulated acidification in the thallus boundary layer where the epibionts occur. Like in the global ocean, Baltic Sea $p \mathrm{CO}_{2}$ is predicted to increase, however the amount of this increase remains unknown (Schneider, 2011). This incertitude is caused by the simultaneous but sometimes op5 posite shift of different parameters: increase of mean sea surface temperature by 2 to $3.5^{\circ} \mathrm{C}$, strengthening of westerly wind, increase of the river run off provoking a decrease of sea surface salinity and increase of inputs of dissolved organic carbon (Schrum, 2001; Gräwe and Burchard, 2011). Locally, in the nearshore ecosystems of the Western Baltic, offshore winds may lead to an upwelling of deoxygenated deeper 10 water increasing the $\mathrm{pCO}_{2}$ to more than $2500 \mu$ atm (Thomsen et al., 2010; Saderne et al., 2012). Strengthening of these winds plus enhanced eutrophication (intensifying anoxic events) might prolong the duration of those hypercapnics events. Consequently, even epibionts in the boundary layer of macroalgae may ultimately be affected by global change directly - and also indirectly by shifts in the physiology and distribution of their host algae. This study illustrates, however, that small scale processes at the habitat or microhabitat scale must be considered when assessing the impact of acidification on species and communities.

Acknowledgements. We thank M. Fischer, C. Hiebenthal, C. Howe, B. Huang Xuan, C. Lieberum, K. Maczassek and C. Pansch, Y. Sawall and the crew of the F. B. Polarfuchs for their field assistance and J.-P. Gattuso for providing access to the Airica. This work was funded by the European community, Marie Curie ITN CALMARO (PITN-GA-2008-215157).

\section{References}

Addadi, L., Raz, S., and Weiner, S.: Taking advantage of disorder: amorphous calcium carbonate and its roles in biomineralization, Adv. Mat., 15, 959-970, 2003.

25 Al-Ogily, S. M.: Further experiments on larval behaviour of the tubicolous polychaete Spirorbis inornatus L'Hardy and Quiévreux., J. Exp. Mar. Biol. Ecol., 86, 285-298, 1985.
BGD

9, 3739-3766, 2012

\section{Effect of Ocean acidification on growth}

V. Saderne and M. Wahl

Title Page

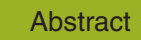

Introduction

Conclusions

Tables

References

Figures

14

$\rightarrow$

$<$

Back

Close

\section{Full Screen / Esc}

Printer-friendly Version

Interactive Discussion 
Beer, T., Israel, A., Helman, Y. and Kaplan, A.: Acidification and $\mathrm{CO}_{2}$ production in the boundary layer during photosynthesis in Ulva rigida (Chlorophyta) C. Agardh, Isr. J. Plant Sci., 56, 5560, 2008.

De Beer, D. and Larkum, A. W. D.: Photosynthesis and calcification in the calcifying algae Halimeda discoidea studied with microsensors, Plant Cell Environ., 24, 1209-1217, 2001.

Bergman, N. and Lenton, T.: COPSE: a new model of biogeochemical cycling over Phanerozoic time, Am. J. Sci., 304, 397-437, 2004.

Boaden, P., O'connor, R., and Seed, R.: The composition and zonation of a Fucus serratus community in Strangford Lough, Co. Down, J. Exp. Mar. Biol. Ecol., 17, 111-136, 1975.

Bornhold, B. D. and Milliman, J. D.: Generic and environmental control of carbonate mineralogy in Serpulid (polychaete) tubes, J. Geol., 81, 363-373, 1973.

Cocito, S.: Bioconstruction and biodiversity: their mutual influence, Sci. Mar, 68, 137-144, 2004.

Collatz, G. J., Berry, J. A., and Clark, J. S.: Effects of climate and atmospheric $\mathrm{CO}_{2}$ partial pressure on the global distribution of $\mathrm{C} 4$ grasses: present, past, and future, Oecologia, 114, 441-454, 1998.

Comeau, S.: Key arctic pelagic mollusc (Limacina helicina) threatened by ocean acidification, Atomic Energy, 6, 2523-2537, 2009.

Daly, J. M.: The annual cycle and the short term periodicity of breeding in a Northumberland population of Spirorbis spirorbis (Polychaeta: Serpulidae), J. Mar. Biol. Assoc. UK, 58, 161176, 1978.

Daly, J. M. and Golding, D. W.: A description of the spermatheca of Spirorbis spirorbis (L.) (Polychaeta: Serpulidae) and evidence for a novel mode of sperm transmission, J. Mar. Biol. Assoc. UK, 57, 219-227, 1977.

Desrosiers, R. R., Désilets, J., and Dubé, F.: Early developmental events following fertilization in the giant scallop Placopecten magellanicus, Can. J. Fish Aquat. Sci., 53, 1382-1392, 1996.

Diaz-Pulido, G., Gouezo, M., Tilbrook, B., Dove, S., and Anthony, K. R. N. N.: High $\mathrm{CO}_{2}$ enhances the competitive strength of seaweeds over corals, Ecol. Lett., 14, 156-162, 2011.

Dickson, A. G.: Standard potential of the reaction: $\mathrm{AgCl}(\mathrm{s})+1 / 2 \mathrm{H}_{2}(\mathrm{~g})=\mathrm{Ag}(\mathrm{s})+\mathrm{HCl}(\mathrm{aq})$, and 30 the standard acidity constant of the ion $\mathrm{HSO}_{4}^{-}$in synthetic sea water from 273.15 to 318.15 K, J. Chem. Thermodyn., 22, 113-127, 1990.
BGD

9, 3739-3766, 2012

\section{Effect of Ocean acidification on growth}

V. Saderne and M. Wahl

Title Page

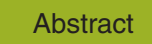

Introduction

Conclusions

References

Tables

Figures

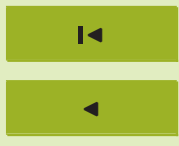

$\rightarrow 1$

Back

Close

Full Screen / Esc

Printer-friendly Version

Interactive Discussion 
Dickson, A. G., Sabine, C. L., and Christian, J. R. (Eds.): Guide to Best Practices for Ocean $\mathrm{CO}_{2}$ Measurements. PICES Special Publication 3. CDIAC, Oak Ridge National Laboratory, US Department of Energy, Oakridge, TN, USA, 2007.

Dissard, D., Nehrke, G., Reichart, G. J., Nouet, J., and Bijma, J.: Effect of the fluorescent indicator calcein on $\mathrm{Mg}$ and $\mathrm{Sr}$ incorporation into foraminiferal calcite, Geochem. Geophy. Geosy., 10, 1-13, 2009.

Dixon, J., Schroeter, S. C., and Kastendiek, J.: Effects of the encrusting bryozoan, Membranipora Membranacea, on the loss of blades and fronds by the giant kelp, Macrocystis Pyrifera (Laminaria), J. Phycol., 17, 341-345, 1981.

10 Dupont, S., Havenhand, J., Thorndyke, W., Peck, L., and Thorndyke, M. C.: Near-future level of $\mathrm{CO}_{2}$-driven ocean acidification radically affects larval survival and development in the brittlestar Ophiothrix fragilis, Mar. Ecol. Prog. Ser., 373, 285-294, 2008.

Ellis, R. P., Bersey, J., Rundle, S. D., Hall-Spencer, J. M., and Spicer, J. I.: Subtle but significant effects of $\mathrm{CO}_{2}$ acidified seawater on embryos of the intertidal snail, Littorina obtusata, Aquat.

15 Biol., 5, 41-48, 2009.

Fabry, V. J., Seibel, B. A., Feely, R. A., and Orr, J. C.: Impacts of ocean acidification on marine fauna and ecosystem processes, ICES J. Mar. Sci., 65, 414-432, 2008.

Graham, J. B., Dudley, R., Aguilar, N. M., and Gans, C.: Implications of the late Paleozoic oxygen pulse for physiology and evolution, Nature, 375, 117-120, 1995.

20

Gräwe, U. and Burchard, H.: Global Change and Baltic Coastal Zones, in: Global Change and Baltic Coastal Zones, vol. 1, edited by: Schernewski, G., Hofstede, J., and Neumann, T., 3-22, Springer Netherlands, Dordrecht, 2011.

Hagerman, L.: The Macro- and Microfauna associated with Fucus serratus L., with some ecological remarks, Ophelia, 3, 1-43, 1966.

Harder, T., Lau, S. C. K., Dahms, H.-U., and Qian, P.-Y.: Isolation of bacterial metabolites as natural inducers for larval settlement in the marine polychaete Hydroides elegans (Haswell), J. Chem. Ecol., 28, 2029-2043, 2002.

Harvell, D.: Why nudibranchs are partial predators: intracolonial variation in bryozoan palatability, Ecology, 65, 716-724, 1984.

30 Hermansen, P., Larsen, S. P., and Riisgard, H. U.: Colony growth rate of encrusting marine bryozoans (Electra pilosa and Celleporella hyalina), J. Exp. Mar. Biol. Ecol., 263, 1-23, 2001.

\section{BGD}

9, 3739-3766, 2012

\section{Effect of Ocean acidification on growth}

V. Saderne and M. Wahl

Title Page

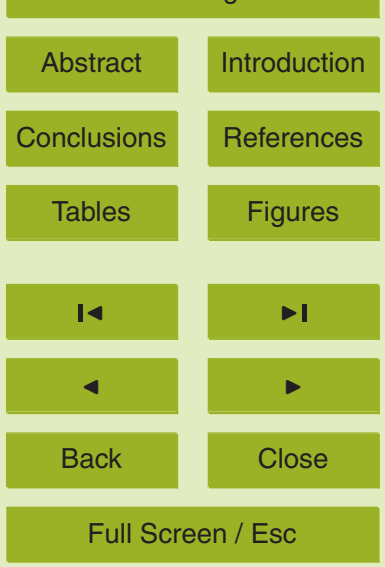

Printer-friendly Version

Interactive Discussion 
Hurd, C. L., Durante, K. M., Chia, F.-S., and Harrison, P. J.: Effect of bryozoan colonization on inorganic nitrogen acquisition by the kelps Agarum fimbriatum and Macrocystis integrifolia, Mar. Biol., 121, 167-173, 1994.

Jablonski, D., Lidgard, S., and Taylor, P. D.: Comparative ecology of bryozoan radiations: origin of novelties in cyclostomes and cheilostomes, Palaios, 12, 505-523, 1997.

Kautsky, H., Kautsky, L., Kautsky, N., Kautsky, U., and Lindblad, C.: Studies on the Fucus vesiculosus community in the Baltic Sea, Acta Phytogeographica Suecica, 78, 33-48, 1992.

Kersen, P., Kotta, J., Bučas, M., Kolesova, N., Dekkere, Z., Epiphytes and associated fauna on the brown alga Fucus vesiculosus in the Baltic and the North Seas in relation to different abiotic and biotic variables, Mar. Ecol., 32, 87-95, 2011.

Knight-Jones, E. W.: Gregariousness and Some other aspects of the setting behaviour of spirorbis, J. Mar. Biol. Assoc. UK, 30, 201-222, 1951.

Knight-Jones, E. W., Knight-Jones, P., and Vine, P. J.: Anchorage of embryos in Spirorbinae (Polychaeta), Mar. Biol., 12, 289-294, 1972.

15 Krumhansl, K. and Scheibling, R.: Detrital production in Nova Scotian kelp beds: patterns and processes, Mar. Ecol. Prog. Ser., 421, 67-82, 2011.

Kuffner, I. B., Andersson, A. J., Jokiel, P. L., Rodgers, K. S., and Mackenzie, F. T.: Decreased abundance of crustose coralline algae due to ocean acidification, Nature Geosci., 1, 114117, 2007.

20 Kurihara, $\mathrm{H}$.: Effects of $\mathrm{CO}_{2}$-driven ocean acidification on the early developmental stages of invertebrates, Mar. Ecol. Prog. Ser., 373, 275-284, 2008.

Kurihara, $\mathrm{H}$. and Shirayama, Y.: Effects of increased atmospheric $\mathrm{CO}_{2}$ on sea urchin early development, Mar. Ecol. Prog. Ser., 274, 161-169, 2004.

Lau, S. C. K. and Qian, P.-Y.: Phlorotannins and related compounds as larval settlement inhibitors of the tube-building polychaete Hydroides elegans, Mar. Ecol. Prog. Ser., 159, 219227, 1997.

Lavigne, H. and Gattuso, J. P.: Seacarb: seawater carbonate chemistry with R. R package version 2.3. 3, http://cran.r-project.org/web/packages/seacarb, 2010.

Lidgard, S. and Jackson, J. B. C.: Growth in encrusting cheilostome bryozoans: I. Evolutionary trends, Paleobiology, 15, 255-282, 1989.

Lisbjerg, D. and Petersen, J.: Feeding activity, retention efficiency, and effects of temperature and particle concentration on clearance rate in the marine bryozoan Electra crustulenta, Mar. Ecol. Prog. Ser., 215, 133-141, 2001.

\section{BGD}

9, 3739-3766, 2012

\section{Effect of Ocean acidification on growth}

V. Saderne and M. Wahl

Title Page

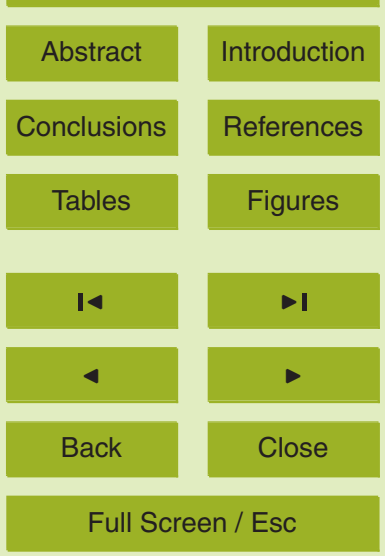

Printer-friendly Version

Interactive Discussion 
Munoz, J., Cancino, J. M., and Molina, M. X.: Effects on encrusting bryozoans on the physiology of their algal substratum, J. Mar. Biol. Assoc. UK, 71, 877-882, 1991.

Martin, S., Rodolfo-Metalpa, R., Ransome, E., Rowley, S., Buia, M.-C., Gattuso, J.-P., and HallSpencer, J. M.: Effects of naturally acidified seawater on seagrass calcareous epibionts, Biol. $5 \quad$ Lett., 4, 689-692, 2008.

Maybury, C. A. and Gwynn, I. A.: Wet processing of recent calcareous foraminifera: methods for preventing dissolution, J. Micropalaeontol., 12, 67-69, 1993.

Millero, F. J.: Carbonate constants for estuarine waters, Mar. Freshwater Res., 62, 139-142, 2010.

10 Morse, J., Andersson, A. J., and Mackenzie, F. T.: Initial responses of carbonate-rich shelf sediments to rising atmospheric $p \mathrm{CO}_{2}$ and "ocean acidification": Role of high Mg-calcites, Geochim. Cosmochim. Ac., 70, 5814-5830, 2006.

Munday, P. L., Dixson, D. L., Donelson, J. M., Jones, G. P., Pratchett, M. S., Devitsina, G. V., and Døving, K. B.: Ocean acidification impairs olfactory discrimination and homing ability of

15 a marine fish, P. Natl. Acad. Sci. USA., 106, 1848-1852, 2009.

Nasrolahi, A., Stratil, S. B., Jacob, K. J., and Wahl, M.: A protective coat of microbes on macroalgae: inhibitory effects of bacterial biofilms and epibiotic microbial assemblages on barnacle attachment, FEMS Microbiol. Ecol., in review, 2012.

Nestler, E. C. and Harris, L. G.: The importance of omnivory in: Strongylocentrotus droebachiensis (Müller) in the Gulf of Maine, in Echinoderms Through Time, edited by: David, B., Guille, A., Féral, J.-P., and Roux, M., CRC press, Rotterdam, 813-818, 1994.

Nott, J. A. and Parkes, K. R.: Calcium accumulation and secretion in the Serpulid polychaete Spirorbis spirorbis L. at settlement, J. Mar. Biol. Assoc. UK, 55, 911-923, 1975.

Orr, J. C., Fabry, V. J., Aumont, O., Bopp, L., Doney, S. C., Feely, R. A., Gnanadesikan, A., Gruber, N., Ishida, A., Joos, F., Key, R. M., Lindsay, K., Maier-Reimer, E., Matear, R., Monfray, P., Mouchet, A., Najjar, R. G., Plattner, G.-K., Rodgers, K. B., Sabine, C. L., Sarmiento, J. L., Schlitzer, R., Slater, R. D., Totterdell, I. J., Weirig, M.-F., Yamanaka, Y., and Yool, A.: Anthropogenic ocean acidification over the twenty-first century and its impact on calcifying organisms, Nature, 437, 681-686, 2005.

30 Oswald, R., Telford, N., Seed, R., and Happey-Wood, C.: The effect of encrusting bryozoans on the photosynthetic activity of Fucus serratus L., Estuar. Coast. Shelf. S., 19, 697-702, 1984.

O'Connor, R. J. and Lamont, P.: The spatial organization of an intertidal spirorbis community, J. Exp. Mar. Biol. Ecol., 32, 143-169, 1978.

\section{BGD}

9, 3739-3766, 2012

\section{Effect of Ocean acidification on growth}

V. Saderne and M. Wahl

Title Page

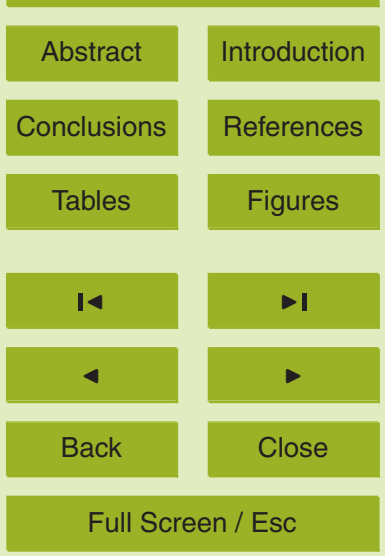

Printer-friendly Version

Interactive Discussion 
Perez, F. F. and Fraga, F.: The pH measurements in seawater on the NBS scale, Mar. Chem., 21, 315-327, 1987.

Potswald, H. E.: Observations on the genital segments of spirorbis (Polychaeta), Bio. Bull., 132, 91-107, 1967.

5 Prentice, I. C. and Harrison, S. P.: Ecosystem effects of $\mathrm{CO}_{2}$ concentration: evidence from past climates, Clim. Past, 5, 297-307, doi:10.5194/cp-5-297-2009, 2009.

Qian, P. Y.: Larval settlement of polychaetes, Hydrobiologia, 402, 239-253, 1999.

Ridgwell, A., Zondervan, I., Hargreaves, J. C., Bijma, J., and Lenton, T. M.: Assessing the potential long-term increase of oceanic fossil fuel $\mathrm{CO}_{2}$ uptake due to $\mathrm{CO}_{2}$-calcification feedback,

10 Biogeosciences, 4, 481-492, doi:10.5194/bg-4-481-2007, 2007.

Ries, J. B.: Skeletal mineralogy in a high-CO ${ }_{2}$ world, J. Exp. Mar. Biol. Ecol., 403, 54-64, 2011.

Ries, J. B., Cohen, A. L., and McCorkle, D. C.: Marine calcifiers exhibit mixed responses to $\mathrm{CO}_{2}$-induced ocean acidification, Geology, 37, 1131-1134, 2009.

Rodolfo-Metalpa, R., Lombardi, C., Cocito, S., Hall-Spencer, J. M., and Gambi, M. C.: Effects 15 of ocean acidification and high temperatures on the bryozoan Myriapora truncata at natural $\mathrm{CO}_{2}$ vents, Mar. Ecol., 31, 447-456, 2010.

Rodolfo-Metalpa, R., Houlbrèque, F., Tambutté, É., Boisson, F., Baggini, C., Patti, F. P., Jeffree, R., Fine, M., Foggo, A., Gattuso, J.-P. and Hall-Spencer, J. M.: Coral and mollusc resistance to ocean acidification adversely affected by warming, Nature Climate Change, 1, 308-312, 202011.

Rucker, J. B. and Carver, R. E.: A survey of the carbonate mineralogy of Cheilostome Bryozoa, J. Paleontol., 43, 791-799, 1969.

Ryland, J. S. and Stebbing, A. R. D.: Settlement and orientated growth in epiphytic and epizoic bryozoans, edited by: Crisp, D. J., Proc. IVth European mar. biol. Symp., University Press, 25 Cambridge, 105-123, 1971.

Saderne, V., Fietzek, P., Herman, P. M. J., and Wahl M.: Extreme variations of $p \mathrm{CO}_{2}$ and $\mathrm{pH}$ in a macrophyte meadow of the Baltic Sea in summer: evidence of the effect of photosynthesis and local upwelling, in preparation, 2012.

Saier, B. and Chapman, A. S.: Crusts of the alien bryozoan Membranipora membranacea can 30 negatively impact spore output from native kelps (Laminaria longicruris), Bot. Mar., 47, 265271, 2004.

\section{BGD}

9, 3739-3766, 2012

\section{Effect of Ocean acidification on growth}

V. Saderne and M. Wahl

Title Page

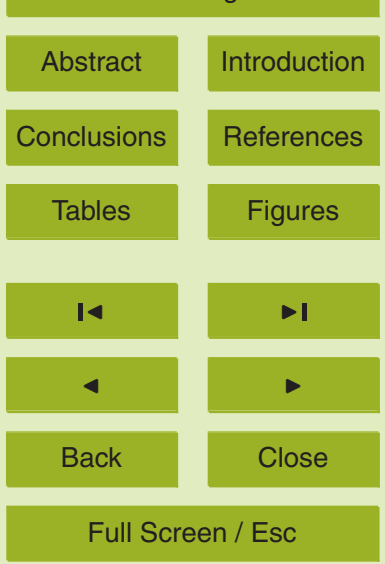

Printer-friendly Version

Interactive Discussion 
Scheibling, R. E., Hennigar, A. W., and Balch, T.: Destructive grazing, epiphytism, and disease: the dynamics of sea urchin - kelp interactions in Nova Scotia, Can. J. Fish Aquat. Sci., 56, 2300-2314, 1999.

Schrum, C.: Regionalization of climate change for the North Sea and Baltic Sea, Clim. Res., 18, 31-37, 2001.

Seed, R.: Observations on the ecology of membranipora (Bryozoa) and a major predator Doridella stelnbergae (Nudibranchiata) along the fronds of Laminaria saccharina at Friday Harbor, Washington, J. Exp. Mar. Biol. Ecol., 24, 1-17, 1976.

De Silva, P. H. D. H.: Experiments on choice of substrata by spirorbis larvae (Serpulidae), J. Exp. Biol., 39, 483-490, 1962.

Smith, A. M., Stewart, B., Key, M., and Jamet, C. M.: Growth and carbonate production by adeonellopsis (Bryozoa: Cheilostomata) in Doubtful Sound, New Zealand, Palaeogeogr. Palaeoclim., 175, 201-210, 2001.

Smith, A. M., Keyjr, M., and Gordon, D.: Skeletal mineralogy of bryozoans: Taxonomic and temporal patterns, Earth-Sci. Rev., 78, 287-306, 2006.

Spilling, K., Titelman, J., Greve, T. M., and Kühl, M.: Microsensor measurements of the external and internal microenvironment of Fucus vesiculosus (Phaeophyceae), J. Phycol., 46, 1350$1355,2010$.

Stanley, S. M.: Influence of seawater chemistry on biomineralization throughout Phanerozoic time: paleontological and experimental evidence, Palaeogeogr. Palaeoclim., 232, 214-236, 2006.

Taylor, P. D., James, N. P., Bone, Y., Kuklinski, P., and Kyser, T. K.: Evolving mineralogy of Cheilostome bryozoans, Palaios, 24, 440-452, 2009.

Thomas, H. and Schneider, B.: The seasonal cycle of carbon dioxide in Baltic Sea surface waters, J. Mar. Syst., 22, 53-67, 1999.

Thomsen, J., Gutowska, M. A., Saphörster, J., Heinemann, A., Trübenbach, K., Fietzke, J., Hiebenthal, C., Eisenhauer, A., Körtzinger, A., Wahl, M., and Melzner, F.: Calcifying invertebrates succeed in a naturally $\mathrm{CO}_{2}$-rich coastal habitat but are threatened by high levels of future acidification, Biogeosciences, 7, 3879-3891, doi:10.5194/bg-7-3879-2010, 2010.

30 Tyrrell, T., Schneider, B., Charalampopoulou, A., and Riebesell, U.: Coccolithophores and calcite saturation state in the Baltic and Black Seas, Biogeosciences, 5, 485-494, doi:10.5194/bg-5-485-2008, 2008.
BGD

9, 3739-3766, 2012

Effect of Ocean

acidification on growth

V. Saderne and M. Wahl

Title Page

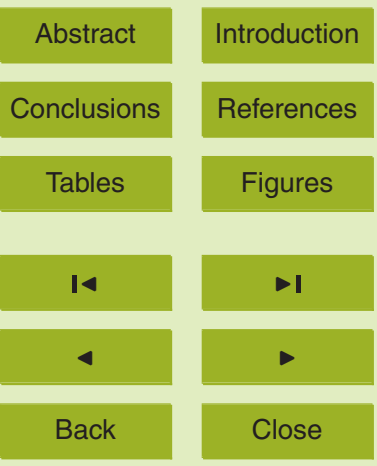

Full Screen / Esc

Printer-friendly Version

Interactive Discussion 
Vinn, O., Ten Hove, H. A., Mutvei, H., and Kirsimäe, K.: Ultrastructure and mineral composition of Serpulid tubes (Polychaeta, Annelida), Zool. J. Linn. Soc-Lond., 154, 633-650, 2008.

Wahl, M., Shahnaz, L., Dobretsov, S., Saha, M., Symanowski, F., David, K., Lachnit, T., Vasel, M., and Weinberger, F.: Ecology of antifouling resistance in the bladder wrack Fucus vesiculosus: patterns of microfouling and antimicrobial protection, Mar. Ecol. Prog. Ser., 411, 33-48, 2010.

Weiner, S.: An overview of biomineralization processes and the problem of the vital effect, Reviews in Mineralogy and Geochemistry, 54, 21-40, 2003.

Weiner, S. and Addadi, L.: Crystallization pathways in biomineralization, Ann. Rev. Mater. Res., 41, 21-40, 2011.

Wharton, W. G. and Mann, K. H.: Relationship between destructive grazing by the sea urchin Strongylocentrotus droebachiensis, and the abundance of american lobster, Homarus americanus, on the Atlantic coast of Nova Scotia, Can. J. Fish Aquat. Sci., 38, 1339-1349, 1981.

Woods, H. A. and Podolsky, R. D.: Photosynthesis drives oxygen levels in macrophyteassociated gastropod egg masses, Biol. Bull., 213, 88-94, 2007.

\section{BGD}

9, 3739-3766, 2012

\section{Effect of Ocean acidification on growth}

V. Saderne and M. Wahl

Title Page

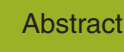

Introduction

Conclusions

References

Tables

Figures

14

4

Back

Full Screen / Esc

Printer-friendly Version

Interactive Discussion 
BGD

9, 3739-3766, 2012

\section{Effect of Ocean acidification on growth}

V. Saderne and M. Wahl

Table 1. Seawater carbonate system in the experimental flasks, derived from $\mathrm{DIC}$ and $\mathrm{pH}_{\mathrm{T}}$, data are the means \pm SD of three flasks sampled every three days before water exchange, along the 30 days duration of the experiment $(n=10)$.

\begin{tabular}{|c|c|c|c|c|c|c|c|c|}
\hline Treatment & $\begin{array}{l}T^{\circ} \\
\left({ }^{\circ} \mathrm{C}\right)\end{array}$ & $\begin{array}{l}\text { Salinity } \\
\text { (psu) }\end{array}$ & $\mathrm{pH}_{\mathrm{T}}$ & $\begin{array}{l}p \mathrm{CO}_{2} \\
(\mu \mathrm{atm})\end{array}$ & $\begin{array}{c}\text { DIC } \\
\left(\mu \mathrm{mol} \mathrm{kg}{ }^{-1}\right)\end{array}$ & $\begin{array}{c}\mathrm{A}_{T} \\
\left(\mu \mathrm{mol} \mathrm{kg}{ }^{-1}\right)\end{array}$ & $\Omega_{\text {arag }}$ & $\Omega_{\text {calc }}$ \\
\hline Control & $16.1 \pm 0.7$ & $16.7 \pm 0.4$ & $8.105 \pm 0.031$ & $460.56 \pm 59.42$ & $1966.4 \pm 40.4$ & $2089.2 \pm 52.5$ & $1.80 \pm 0.22$ & $3.02 \pm 0.34$ \\
\hline $3150 \mu a t m$ & $15.9 \pm 0.8$ & $16.8 \pm 0.4$ & $7.334 \pm 0.079$ & $3150.40 \pm 445.73$ & $2306.8 \pm 251.8$ & $2298.9 \pm 57.5$ & $0.40 \pm 0.09$ & $0.66 \pm 0.14$ \\
\hline
\end{tabular}

Title Page

Abstract Introduction

Conclusions

References

Tables

\section{Figures}

14

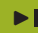

4

Back

\section{Full Screen / Esc}

Printer-friendly Version

Interactive Discussion 


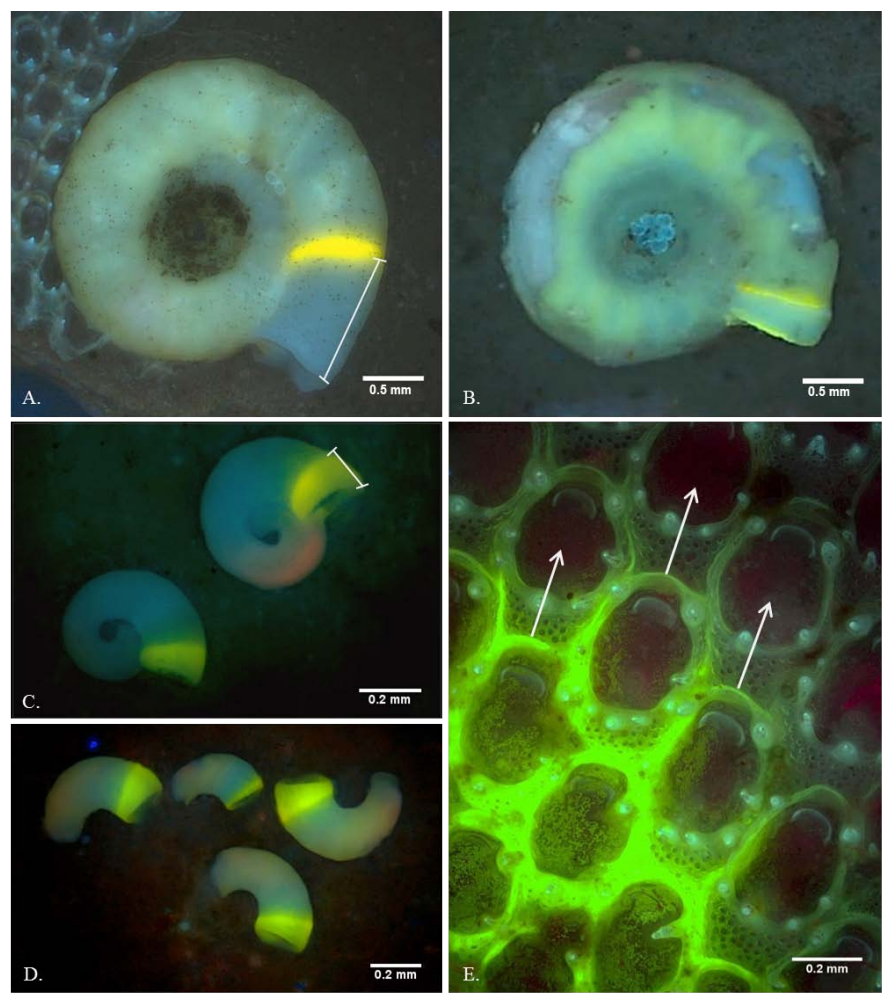

Fig. 1. Illustrative examples of Spirorbis spirorbis and Electra pilosa. (A, B) Adult Spirorbis spirorbis tubes after 30 day incubation at $460 \mu \mathrm{atm}$ and $3150 \mu \mathrm{atm} \mathrm{CO}_{2}$ respectively. (C, D) Juveniles Spirorbis spirorbis tubes after 30 day incubation at $460 \mu \mathrm{atm}$ and $3150 \mu \mathrm{atm} \mathrm{CO}_{2}$ respectively. Note the important dissolution of the shell in $B$. and the disappearance of part of the tube in (D). (E) Electra pilosa colony. All photos were taken under epifluorescence microscope, yellow/green: calcein staining. The white lines are showing the considered distances for the growth measurements of spirorbis tubes. Arrows indicate the direction of the growth subsequent to the calcein staining in Electra.

BGD

9, 3739-3766, 2012

\section{Effect of Ocean acidification on growth}

V. Saderne and M. Wahl

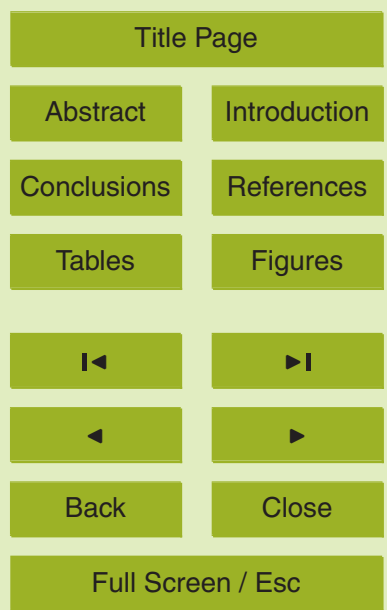

Printer-friendly Version

Interactive Discussion 


\section{BGD}

9, 3739-3766, 2012
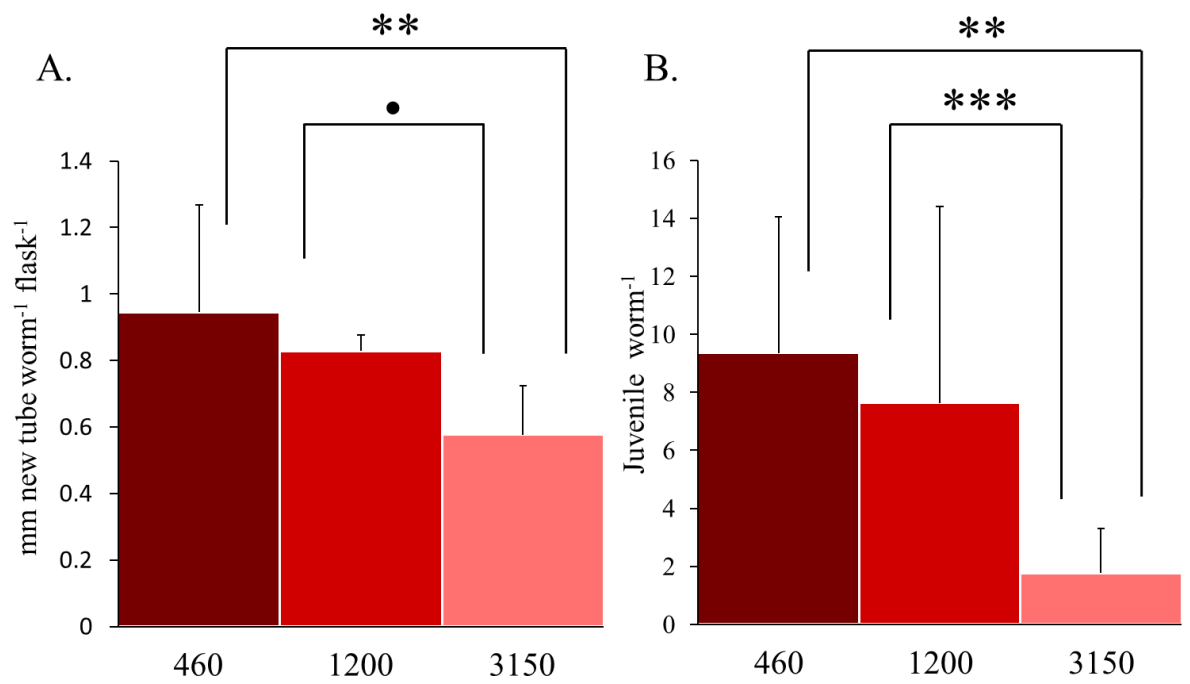

\section{Effect of Ocean acidification on growth}

V. Saderne and M. Wahl

Title Page

Abstract Introduction

Conclusions

References

Tables

Figures

Fig. 2. (A) Growth of the tubes of Spirorbis spirorbis during the 30 days incubations at $460 \mu a t m$, $1200 \mu$ atm and $3150 \mu$ atm $\mathrm{CO}_{2}$, data are the mean $\pm \mathrm{SD}$ of newly formed tubes sections in $\mathrm{mm}$ per worm per flask. (B) Recrutement of Spirorbis spirorbis during the 30 days incubations at $460 \mu$ atm, $1200 \mu \mathrm{atm}$ and $3150 \mu$ atm $\mathrm{CO}_{2}$, data are the mean $\pm \mathrm{SD}$ of the number of juveniles settled per adult between flasks. One-way ANOVAs, $n=10$, statistical significance: ${ }^{* * *}: p \leq$ $0.001,{ }^{* *}: p \leq 0.01,{ }^{*}: p \leq 0.05, \bullet: p<0.1$.

14

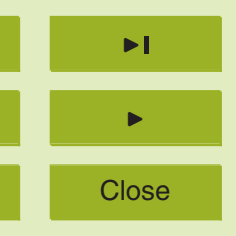

\section{4}

Back
Full Screen / Esc

Printer-friendly Version

Interactive Discussion 


\section{BGD}

\section{9, 3739-3766, 2012}

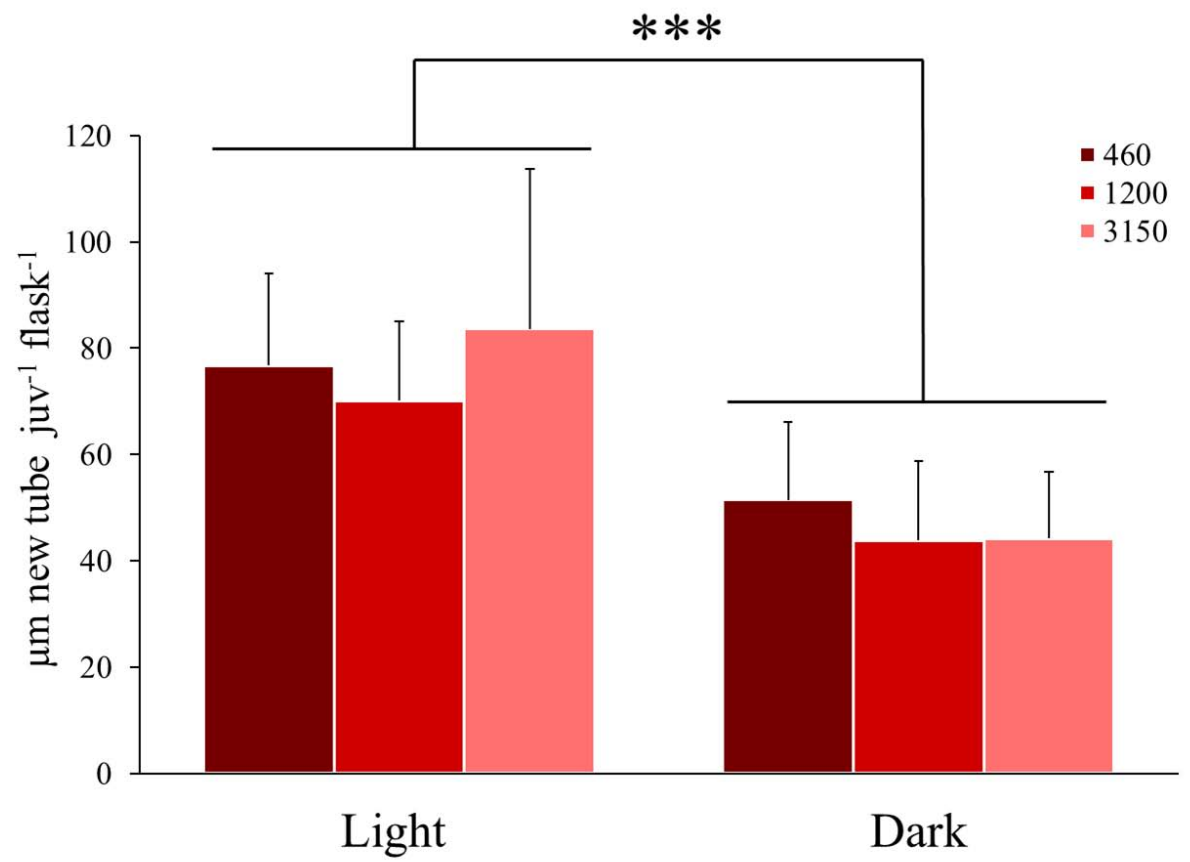

Fig. 3. Growth in $\mu \mathrm{m}$ of the tubes of the juveniles of Spirorbis spirorbis during $24 \mathrm{~h}$ in light and dark condition exposed to $p \mathrm{CO}_{2}$ of $460 \mu \mathrm{atm}, 1200 \mu \mathrm{atm}$ and $3150 \mu \mathrm{atm}$. Two-way ANOVA, $n=5$, statistical significance: ${ }^{* * *}: p \leq 0.001$.

\section{Effect of Ocean acidification on growth}

V. Saderne and M. Wahl

Title Page

Abstract

Introduction

Conclusions

References

Tables

Figures

।

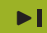

4

Back

\section{Full Screen / Esc}

Printer-friendly Version

Interactive Discussion 
BGD

9, 3739-3766, 2012

Fig. 4. Relative growth rate (RGR) of (A) Electra pilosa, (B) Alcyonidium hirsutum colonies during the 30 days incubations at $460 \mu \mathrm{atm}, 1200 \mu \mathrm{atm}$ and $3150 \mu \mathrm{atm} \mathrm{CO}_{2}$. Data are the mean \pm SD of the growth rates in $\%$ in $n=10$ flasks. ANOVA, statistical significance: ${ }^{* *}$ : $p \leq 0.01$.
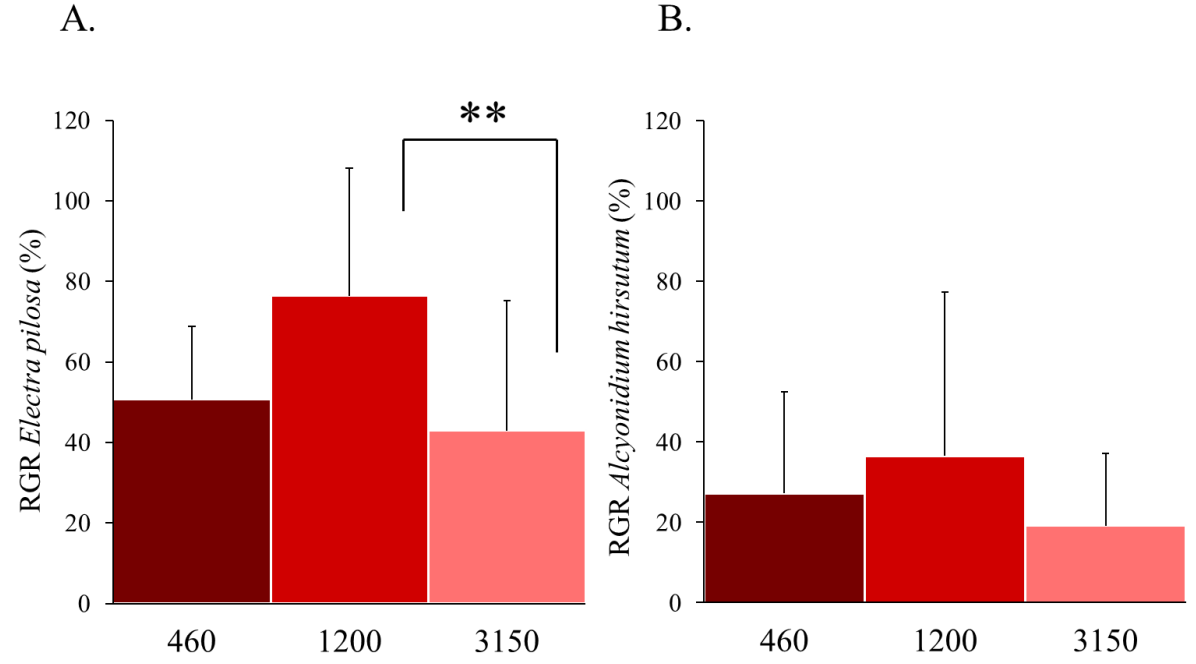

\section{B.}

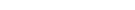

\section{Effect of Ocean
acidification on \\ Effect of Ocean
acidification on growth}

V. Saderne and M. Wahl

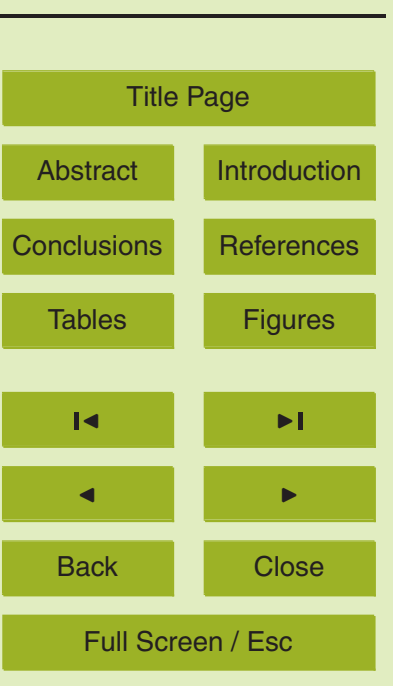

Printer-friendly Version

Interactive Discussion 